\title{
Pampean lizard assemblage from subtropical Brazil: a temporal analysis
}

\author{
GISELE R. WINCK ${ }^{1}$, TIAGO G. DOS SANTOS ${ }^{2}$ and SONIA Z. CECHIN ${ }^{3}$ \\ ${ }^{1}$ Pós-Graduação em Biodiversidade Animal, Universidade Federal de Santa Maria, Laboratório de Herpetologia, \\ Departamento de Biologia, Av. Roraima s/n, Prédio 17, sala 1140, Camobi, 97105-900 Santa Maria, RS, Brasil \\ ${ }^{2}$ Pós-Graduação em Ciências Biológicas (Zoologia), Universidade Estadual Paulista, Laboratório de Herpetologia, \\ Departamento de Zoologia, Instituto de Biociências, Av. 24-A, 1515, Bela Vista, 13506-900 Rio Claro, SP, Brasil \\ Present address: Universidade Federal do Pampa (UNIPAMPA), Campus São Gabriel, \\ Av. Antônio Trilha, 1847, 97300-000 São Gabriel, RS, Brasil \\ ${ }^{3}$ Universidade Federal de Santa Maria, Laboratório de Herpetologia, Departamento de Biologia, \\ Av. Roraima, s/n, Prédio 17, sala 1140, Camobi, 97105-900 Santa Maria, RS, Brasil
}

Manuscript received on September 17, 2010; accepted for publication on May 5, 2011

\begin{abstract}
The increasing human occupation of natural environments is one of the greatest threats to biodiversity. To mitigate the negative anthropogenic effects, it is necessary to understand the characteristics of natural populations and the natural history of species. A study was conducted with an assemblage of lizards from a disturbed area of the Pampa biome, from February 2001 to January 2004. The assemblage showed a unimodal seasonal pattern, with the recruitment period occurring during the warmer months. The captures were seasonal for two of the three monitored years, and concentrated within warmer months. The minimum temperature explained the number of catches for the assemblage as a whole. However, when the species were analyzed individually, the temperature only explained the seasonal occurrence of Teius oculatus. The abundance of species was significantly different in the third year of study for Cercosaura schreibersii and Ophiodes striatus. This latter species was no longer registered in the study area from May 2003 until the end of the study. Therefore, O. striatus may be more sensitive to environmental changes, considering the events of change in vegetation during the study. With frequent and increasing environmental disturbances, it is necessary to take conservation measures and encourage the increase of knowledge on Pampean lizards.
\end{abstract}

Key words: grassland, activities pattern, seasonality, reptiles, unimodal pattern.

\section{INTRODUCTION}

The lizard fauna from Rio Grande do Sul State, Brazil, comprises 20 native species and one exotic (Di-Bernardo et al. 2003). At least 11 of these may inhabit the Pampa biome (southern grasslands), which occupies approximately $50 \%$ of the total state area. Even so, few is known about the natural history and ecology of lizard

Correspondence to: Gisele R. Winck

E-mail: gwinck@yahoo.com.br

Present address: Pós-Graduação em Ecologia e Evolução, Universidade do Estado do Rio de Janeiro, Laboratório de Ecologia de Vertebrados, Departamento de Ecologia, Rua São Francisco Xavier, 524, Maracanã, 20550-013 Rio de Janeiro, RJ, Brasil. populations in this biome (MMA 2000). In Brazil, the Pampa lizard fauna may be considered of little diversity when compared to other biomes, e.g., Atlantic Forest, Cerrado (Brazilian savannah), and Amazonian rainforest. Regarding mammals, the population decrease is more intense in this biome, where intensive cattle breeding and unsustainable agriculture severely damaged it (see Overbeck et al. 2007). It is possible that the reptile fauna also suffers similar pressures, since the structure of a pampean snake assemblage changes due to anthropic pressure (Winck et al. 2007).

Besides life history traits (Niewiarowski 1994), several environmental features can influence life cycle 
patterns, such as temperature, precipitation and sunlight period (Censky 1995), presence of favorable microhabitats to ontogeny (Andrews 1988), environmental predictability (Colli 1991) and food availability (Vrcibradic and Rocha 1998). In Brazil, habitat destruction is the main threat for reptile conservation, and despite open environment species are more resistant than forest ones, many could disappear due to habitat modification, as registered in soybean plantations of the Brazilian Cerrado (Rodrigues 2005). The agriculture and livestock impose great pressure on open ecosystems (Fiszon et al. 2003) by removing microhabitats and shelters, increasing soil exposure, reducing food availability (Silvano et al. 2003) and fragmenting habitat. Likewise, the Pampa in the study region is highly affected by monoculture farming (soybean, rice, corn, Eucalyptus sp., bottle gourd), with a production average of 300.000 tons of rice (IBGE 2008).

The present study identifies the local lizard assemblage and population recruitment. Additionally, it is possible that the distribution of lizard species varies throughout the year. Toledo et al. (2003) and Santos et al. (2007) argued that the temporal distribution of ectotherms (anurans) from the South-eastern Atlantic Forest depends on the rain frequency throughout the year. Several amphibians and reptiles from areas of dry and wet seasons have their annual pattern of activity influenced by rain and temperature (e.g., Bertoluci 1998, Marques et al. 2001, Wiederhecker et al. 2002, Ávila et al. 2010, García et al. 2010). However, recent studies have revealed that the temporal patterns of anurans and snakes in austral assemblages of the Neotropics markedly differ from those recorded for septentrional zones (see Di-Bernardo et al. 2007, Winck et al. 2007, Both et al. 2008, Bujes and Verrastro 2008, Canavero et al. 2008, Santos et al. 2008). For lizards, Waldschmidt and Tracy (1983) also recorded that temperature influenced the temporal distribution of Uta stansburiana in a temperate area of the northern hemisphere. Regarding studies in the Brazilian subtropical zone, Winck and Cechin (2008) and Winck et al. (in press) show temperature as one of the limit factors for the activity of Tupinambis merianae in the southern Rio Grande do Sul State, Brazil. Most information on the activity of Brazilian lizards was acquired in tropical areas, focusing on a single species (e.g., Van Sluys and Rocha 1999, Zaluar and Rocha 2000, Wiederhecker et al. 2003, Peloso et al. 2008). Just a few analyzed more than one species (e.g., Bergallo and Rocha 1993, Vrcibradic and Rocha 1996, Van Sluys et al. 2004), and even fewer considered hole assemblages (e.g., Hatano et al. 2001).

There is a lack of information in the literature on circannual activity pattern of lizards, even greater if we consider the southern region of Brazil. The present study is the first one on the ecology of a lizard assemblage in the Brazilian subtropical region, and one of a few regarding the entire country. Since the study area is a disturbed grassland, we analyzed whether the temporal distribution of this lizard assemblage is guided solely by abiotic features.

\section{MATERIALS AND METHODS}

\section{STUdy AREA}

The study was conducted in grasslands of the Pampa biome located in the Central Depression of the state of Rio Grande do Sul, Brazil $\left(29^{\circ} 44^{\prime} \mathrm{S}, 53^{\circ} 45^{\prime} \mathrm{W}\right.$ ) (see details in Winck et al. 2007). The region has a humid subtropical climatic type (STUM) according to Maluf (2000), with the climatic seasonality being greatly defined by temperature. The annual temperature average is $19.6^{\circ} \mathrm{C}$, with monthly averages varying between $24.8^{\circ} \mathrm{C}$ in January and $14.3^{\circ} \mathrm{C}$ in June. The annual average precipitation is $1.686 \mathrm{~mm}$, with regularly-distributed rain throughout the year (Pereira et al. 1989, Budke et al. 2004). Day length (photoperiod) ranges from $10.14 \mathrm{~h}$ in winter (June) to $14.03 \mathrm{~h}$ in summer (December) (Observatório Nacional Brasileiro. Accessible at http://euler.on.br/ephemeris/index.php, captured in 09/23/2008). Initially, the studied area was a typical grassland used for extensive cattle breeding (February 2001, when the project started). Later, three modifications occurred. In August 2001, the left side of the traps (approximately 69,300 $\mathrm{m}^{2}$ ) was burnt and a corn cultivation was implemented. At the same time, the area between the two axes of the traps was cultivated with bottle gourd (almost 114,000 $\mathrm{m}^{2}$ ). In September 2002, there was new bottle gourd cultivation at the area between the two axes of the traps. Furthermore, in September 2003, a new burnt occurred, and a cultivation of soy bean was 
implemented in both areas. Thus, the only unmodified area was located in de right side of the second axis of the traps until the end of this study (January 2004).

\section{SAMPLING}

Sampling was conducted between February 2001 and January 2004, with each month being considered a sampling unity (total of sampling unities $=36$ ). We used pitfall traps, composed of 30 100-liter barrels placed 15 meters apart from each other, and plastic mesh drift fences set in an "L" shape. The barrels remained open for the whole study period (total of hours $=26,280$ ) and were checked on alternate days during the hightemperature season, and at every three days during the low-temperature season. Occasional captures of lizards in the studied area were also considered. The captured specimens were carefully conditioned into a closed (but breathable) plastic recipient with a wet piece of cotton and taken to the laboratory. Captured individuals were identified, marked by clipping one toe (adapted from Tinkle 1967) to avoid bias in abundance data and sex ratio due to the resampling, and immediately released at the site of capture. The sex was identified through stick insertion in the vent and/or presence of eggs or embryos. We also recorded snout-vent length (SVL, in $\mathrm{mm}$ ), tail length (TL, in mm), and body mass (by Pesola ${ }^{\circledR}$ dynamometers of $0.1 \mathrm{~g}$ precision).

In order to define class ages, we used data from the literature: Cercosaura schreibersii (Balestrin et al. 2010), Mabuya dorsivittata (Vrcibradic et al. 2004), Ophiodes striatus (Montechiaro et al. 2011) and Teius oculatus (Cappellari 2005).

\section{DATA ANALYSIS}

To verify the relationship between the monthly incidence of species (number of captures) and the climatic variables (minimum temperature, monthly average precipitation, and monthly average hours of sunlight) from the studied area, we used the stepwise multiple regression analysis with backward selection (Zar 1999) in the Statistica 6.0 software (Statsoft 2001). To test possible differences in the species abundance throughout the studied years, we used the chi-square analysis through Systat 11 (2004). To evaluate the sexual proportion of each species, we used the Chi-square test for expected equal proportions (Magurran 2004). The temporal flutuations on the assemblage activity was analyzed through a circular statistical analysis (Zar 1999) using ORIANA 2.02 (Kovach 1994-2006). Months were converted into angles (intervals of $30^{\circ}$ ), and richness and abundance of each species per month were taken as frequencies of each observed month (see Prado et al. 2005, Both et al. 2008). Through this method we estimated: I) the mean angle $(\alpha)$, which represents the mean time of the year when most species were active; II) the circular standard deviation (SD, related to $\alpha$ ); and III) the length of the mean vector $(\mathrm{r})$, which is a measure of data concentration around the circle (year), ranging from 0 (scattered data) to 1 (clustered data on the same direction). The Rayleigh's Uniformity Test was used to calculate the probability of the null hypothesis (the data are uniformly distributed around the analyzed cycle) (Zar 1999). A significant result of the Rayleigh test indicates a seasonal activity of the studied lizard assemblage (Kovach 1994-2006). We also performed a multisample test to verify if the monitored cycles (years) did not differ significantly in some way. Thus, we chose a chi-square test because our data are grouped (months around the year) (see Kovach 1994-2006). Whether a significant result occurs, we can reject the null hypothesis and consequently assumed that the monitored cycles differ in any parameter (Kovach 1994-2006).

The temporal distribution of species (monthly) was analyzed by the Morisita-Horn similarity index $(\mathrm{CH})$, with a posterior cluster analysis by the Unweighted Pair Group Method of Arithmetic Averages (UPGMA) (Krebs 1999). In this analysis, we considered only the adult individuals to avoid recruitment interference, as indicated by Marques et al. (2001). Species abundance data were converted into the logarithm form $(n+1)$ to minimize the effects of the most abundant species. We considered valid groups $\mathrm{CH}>0.5$. The information loss in the cluster construction was evaluated by Cophenetic Correlation Coefficient (r) (Romesburg 1984), correlating the original similarity matrix with the obtained matrix from the cluster. The value of $r>0.9$ was considered a very good adjustment; $0.9<\mathrm{r}<0.8$ was considered a good adjustment; $0.8<\mathrm{r}<0.7$ was considered a poor adjustment; and $\mathrm{r}<0.7$ was considered a very poor adjustment (Rohlf 2000). These analyses 
were conducted with the NTSYS 2.1 software (Rohlf 2000). Statistical significances of all analyses were considered when $\mathrm{p}<0.05$.

Minimum temperature values, the average precipitation, and hours of sunlight values were obtained at the Meteorological Station (Departamento de Fitotecnia) of the Universidade Federal de Santa Maria, nearby the studied area (approximately $3 \mathrm{~km}$ ).

\section{RESULTS}

After 36 months of sampling, we captured 351 lizards of six species and five genera, distributed into four families (Table I). The species with the higher number of captures was Cercosaura schreibersii $(36.47 \%, \mathrm{n}=$ 128), followed by Mabuya dorsivittata $(27.35 \%, \mathrm{n}=$ 96), Ophiodes striatus $(20.23 \%, \mathrm{n}=71)$ and Teius oculatus $(14.24 \%, \mathrm{n}=50)$ (Table I). When we compared the species abundance throughout the sampling years (Fig. 1), we verified that the last year had fewer captures $\left(\chi^{2}=4.4, \mathrm{p}=0.05\right.$; randomization test $\mathrm{Q}=209.61$, $\mathrm{p}<0.01)$. However, when we analyzed each species individually, we only found significant differences in the number of captures during the third year for $C$. schreibersii $\left(\chi^{2}=8.33, \mathrm{p}<0.01\right)$ and $O$. striatus $\left(\chi^{2}=\right.$ $9.5, \mathrm{p}<0.01)$. Teius oculatus showed a significant difference of general activity $\left(\chi^{2}=6.5, p=0.03\right)$, with no remarkable year. Recaptures were not considered for all analysis due to its low rate.

In September 2001, there was a disturbance in the study area (soil tilling and monoculture implementation), which affected $69,300 \mathrm{~m}^{2}$ of the left side of the traps (burnt before soil handling), as well as between the two rows of barrels $\left(113,400 \mathrm{~m}^{2}\right)$. This coincided with an expressive increase of Ophiodes striatus abundance. However, this species was no longer found at the area from May 2003 onward (Fig. 2). The newborns entry in the population was mainly observed from December to March, which corresponds to the warm season in the studied area. Males were more abundant from August to April, and females from August to May (Fig. 3). We recorded newborns in the high-temperature season (December to March) to all species, but also in the low-temperature season (June to August) for Cercosaura schreibersii. The sexual proportion differed only for Mabuya dorsivittata $\left(\chi^{2}=12.3, p<0.01\right)$ and
O. striatus $\left(\chi^{2}=27.8, \mathrm{p}<0.01\right)$, with a higher incidence of males.

The circular statistical analysis evidenced a seasonal incidence of lizard captures (Rayleigh test) for two of the three monitored annual cycles (2001-2002 and 2002-2003) (Table II). The mean angle recorded for seasonally significant cycles showed that most captures occurred in the middle summer (January of 2002 and 2003) (Table II). However, the length of the mean vector ( $\mathrm{r}$ ) did not show a strong degree of seasonality in the studied cycles (Table II). In addition, the multi-sample test revealed that the monitored years differed concerning the incidence of lizard captures (Table II).

The similarity analysis showed a species cluster with over $50 \%$ of the temporal distribution overlapping formed by Cercosaura schreibersii, Ophiodes striatus and Mabuya dorsivittata, which had a large temporal occurrence throughout the studied period (Fig. 4). When we analyzed the capture numbers of these species with climatic features, we found that only minimum temperatures explained the incidence of Teius oculatus $\left(\mathrm{R}^{2}=0.29, \mathrm{~F}_{(2,33)}=15.00\right.$, and $\left.\beta=0.55\right)$ (Fig. 5) and the whole assemblage $\left(\mathrm{R}^{2}=0.31, \mathrm{~F}_{(2,33)}=17.02\right.$, and $\beta=0.58$ ) (Table III), since rainfall and hours of sunlight were removed from the model. The incidence of other three lizard species (C. schreibersii, M. dorsivittata, and $O$. striatus) remained unexplained by the tested variables.

\section{DISCUSSION}

The studied assemblage is mainly composed by typical species from open areas or common in open areas (grasslands) (Cei 1993). The exceptions were Mabuya dorsivittata and Tupinambis merianae, which can inhabit woods and/or wooded shores (Ávila-Pires 1995). The species richness recorded on this study comprises $30 \%$ of the lizard fauna of Rio Grande do Sul State (DiBernardo et al. 2003). Concerning the number of captures, the higher abundance of Cercosaura schreibersii could be related to various features, since the analyzed factors do not explain entirely most of the observed variations of its abundance. It may be allied to temporal fluctuations associated with latitude, altitude, humidity, habitat complexity, prey availability, reproductive patterns (Vitt 1987) and phylogeny (Dunham and Miles 
TABLE I

Richness and abundance of lizard species in the studied area, between February 2001 and January 2004, from the Pampa biome in Brazil. $\mathrm{N}=$ captures number; $\mathrm{FR}=$ relative frequency $(\%)$.

\begin{tabular}{lcc}
\hline \multicolumn{1}{c}{ TAXA } & $\mathrm{N}$ & $\mathrm{FR}$ \\
\hline Gymnophtalmidae & & \\
Cercosaura ocellata petersi Ruibal, 1952 & 04 & 1.14 \\
Cercosaura schreibersii (Wiegmann, 1834) & 128 & 36.47 \\
Teiidae & & \\
Teius oculatus (d'Orbigny and Bibron, 1837) & 50 & 14.24 \\
Tupinambis merianae (Duméril and Bibron, 1839) & 02 & 0.57 \\
Scincidae & & \\
Mabuya dorsivittata (Cope, 1862) & 96 & 27.35 \\
Anguidae & & \\
Ophiodes striatus (Wagler, 1828) & 71 & 20.23 \\
Total & 351 & 100 \\
\hline
\end{tabular}

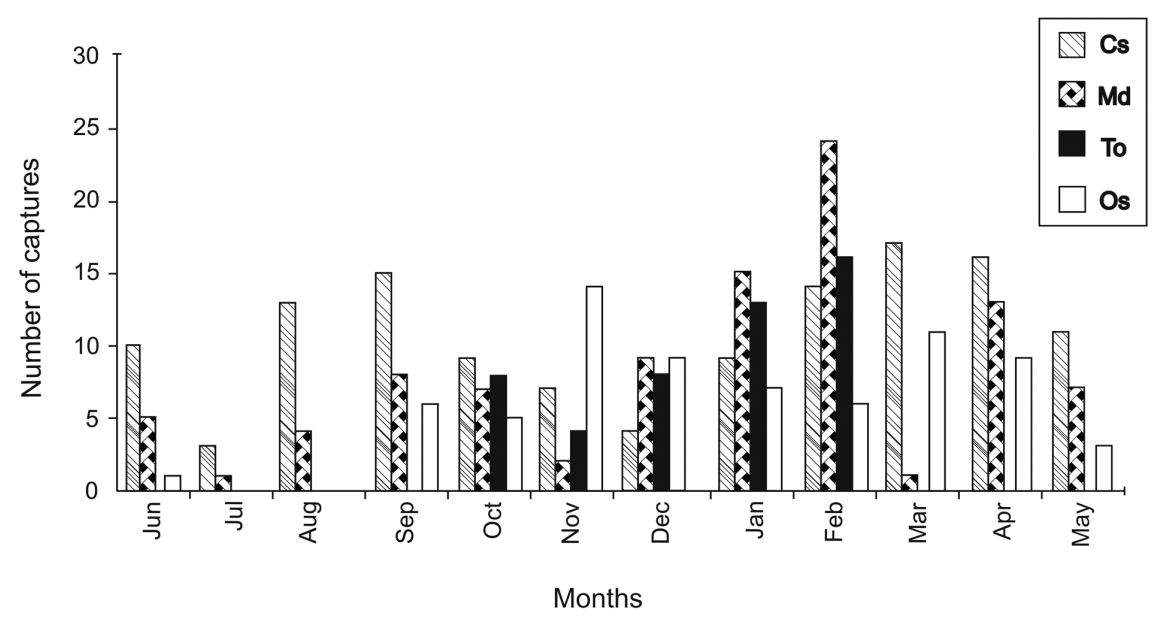

Fig. 1 - Accumulated temporal incidence of individuals from four of the six lizards species recorded in an altered grassy field of southern Brazil, from February 2001 to January 2004. C.s. = Cercosaura schreibersii; M.d. = Mabuya dorsivittata; T.o. = Teius oculatus; O.s. = Ophiodes striatus.

TABLE II

Results of circular statistical analysis testing incidence of captures seasonality of lizards from Pampean area, Brazil. (*) indicates P values significant at $1 \%$.

\begin{tabular}{l|c|c|c}
\hline \multirow{2}{*}{ Variables } & \multicolumn{3}{|c}{ Annual cycles } \\
\cline { 2 - 4 } & $2001-2002$ & $2002-2003$ & $2003-2004$ \\
\hline Number of observations & 160 & 134 & 65 \\
Mean vector $(\mu)$ & $342.669^{\circ}(\mathrm{Jan})$ & $341.066^{\circ}(\mathrm{Jan})$ & $42.363^{\circ}(\mathrm{Mar})$ \\
Length of mean vector $(\mathrm{r})$ & 0.282 & 0.347 & 0.145 \\
Circular standard deviation (SD) & $91.220^{\circ}$ & $83.33^{\circ}$ & $112.525^{\circ}$ \\
Rayleigh test $(\mathrm{Z})$ & $12.685^{*}$ & $16.161^{*}$ & 1.373 \\
$\chi^{2}$ test & $52.100^{*}$ & $52.627^{*}$ & $52.231^{*}$ \\
\hline
\end{tabular}




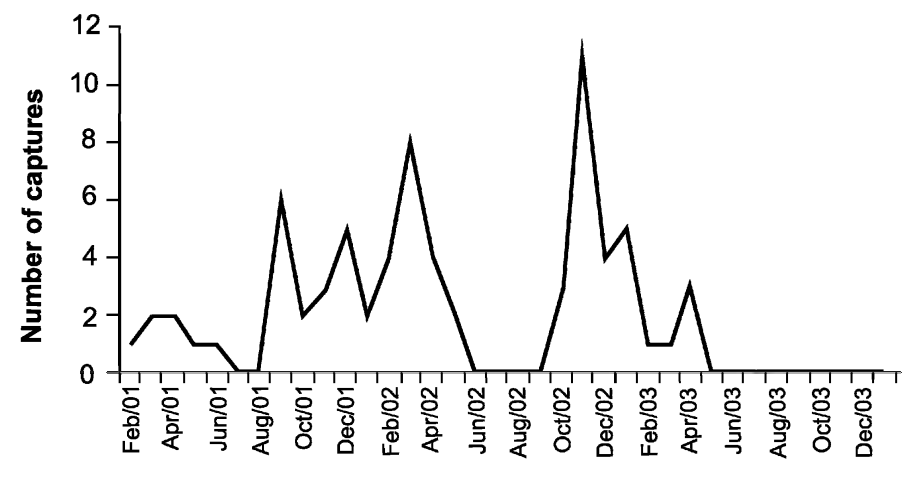

Months

Fig. 2 - Abundance of Ophiodes striatus during the study conducted from February 2001 to January 2004, in an altered grassy field area, municipality of Santa Maria, Rio Grande do Sul state, Brazil.

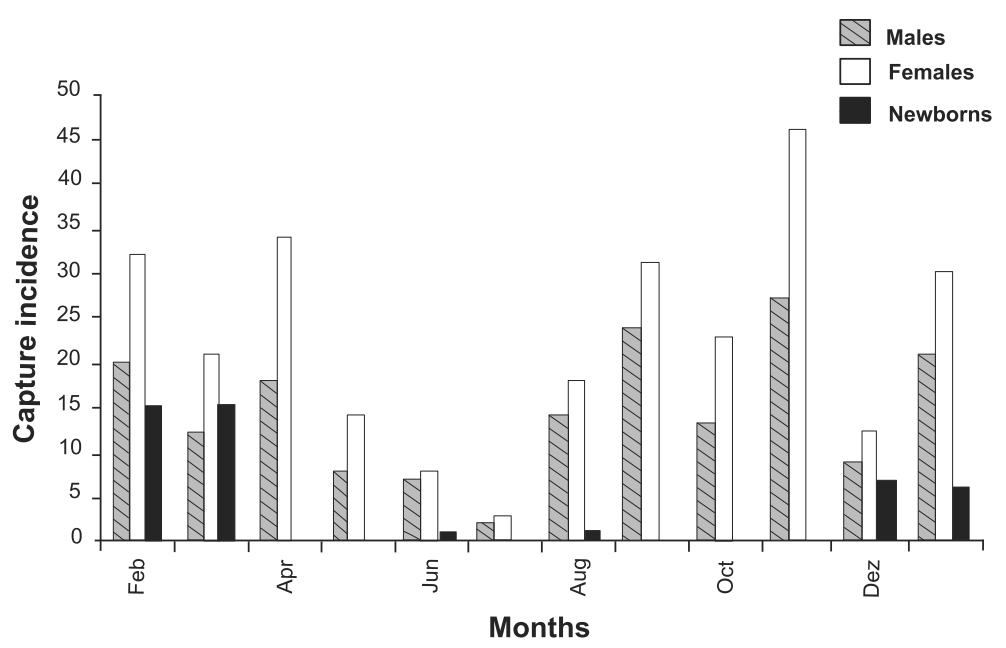

Fig. 3 - Accumulated capture incidence in an altered grassy field, municipality of Santa Maria (Rio Grande do Sul state, Brazil), from February 2001 to January 2004. The black bars indicate newborns, incomplete bars indicate females, and striped bars indicate males.

1985). In Pampa biome, C. schreibersii displays a wide ecological versatility and is capable of finding a large amount of small arthropods to eat (M. Di-Bernardo, pers. comm.). Its lower incidence during the third year and the fewer recaptures $(n=6)$ is probably related to the individuals capacity of learning to avoid traps (M. DiBernardo, pers. comm.). Therefore, we suppose that the prey temporal fluctuations could be the most important factor to be measured in future studies involving this species. However, our data do not allow excluding an alternative hypothesis of the events of the Pampa degradation affecting this species in the last monitored year.
The lower capture incidence for Cercosaura ocellata petersi $(\mathrm{n}=4)$ and Tupinambis merianae $(\mathrm{n}=2)$ did not allow reliable conclusions on these species abundance. The former seems to be naturally rare in the state of Rio Grande do Sul (Anés et al. unpublished data). The latter is a large-bodied species (almost $500 \mathrm{~mm}$ of SVL) with a large home range (resident males may have a minimum home-range of approximately 26.44 ha) (Winck et al. in press). These characteristics of their natural history hinder the capture by pitfall traps. The other species recorded in this study displayed intermediate to high abundance and seemed 


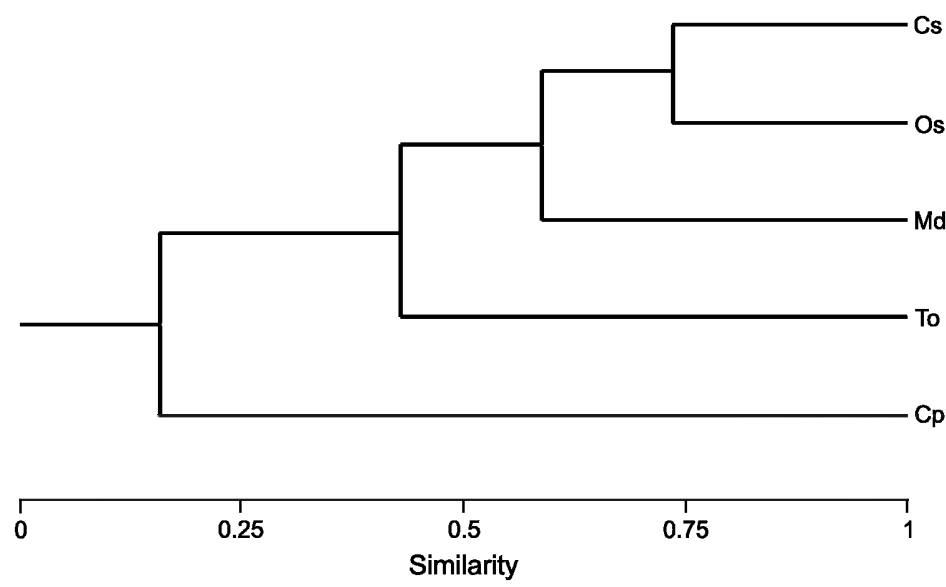

Fig. 4 - Similarity of the temporal distribution among five of the six lizards species studied in the studied area, Rio Grande do Sul, Brazil. Cophenetic Correlation Coefficient: $\mathrm{r}=0.91$. Cs $=$ Cercosaura schreibersii; Os = Ophiodes striatus; $\mathrm{Md}=$ Mabuya dorsivittata $; \mathrm{To}=$ Teius oculatus; $\mathrm{Cp}=$ Cercosaura ocellata petersi .

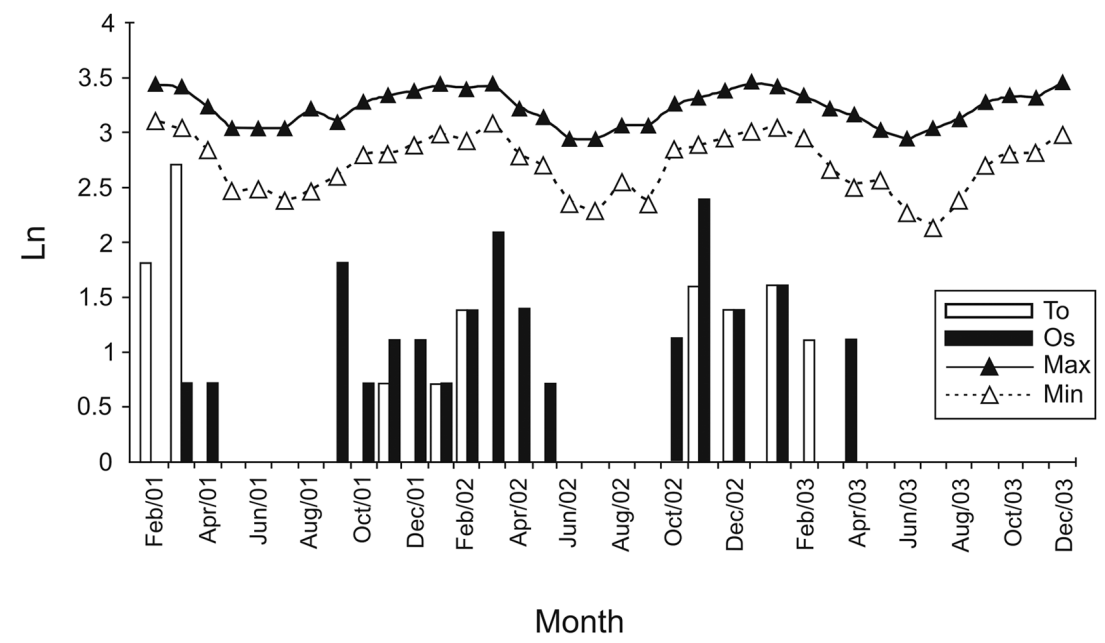

Fig. 5 - Capture incidence of two species versus temperature (minimum and maximum) for the studied area, municipality of Santa Maria, Rio Grande do Sul, Brazil. To = Teius oculatus; Os = Ophiodes striatus; $\mathrm{Max}=$ maximum temperature values; $\mathrm{Min}=$ minimum temperature values. The values were transformed into their natural logarithmic form $(\mathrm{Ln})$.

to maintain stable populations in the studied area, since we did not recorded significant differences in their abundance throughout the monitored years, except for Ophiodes striatus.

Although the biological assemblages for open formations are more resistant to environmental disturbances, microclimates changes and the presence of herbicides, these factors can decrease food resources and available shelters, restricting the tolerance of each individual (Fiszon et al. 2003). Thus, open-formation spe- cies of reptiles can disappear when their habitats are totally eliminated (Rodrigues 2005). In this context, it is possible that the decreasing capture of $O$. striatus is related to successive anthropogenic disturbances in adjacent pitfall areas (burned and monocultures). The first abundance peak of $O$. striatus, occurred in September 2001, which coincides with the initial disturbance in the area (replacement of $113,400 \mathrm{~m}^{2}$ of grassy field by monocultures, in an adjacent area to the traps). The observed capture incidence possibly represents the 
TABLE III

Multiple linear regression analysis for incidence of lizards captures and monthly climatic variables monitored in Pampean area, Rio Grande do Sul State, southern Brazil. (*) indicates statistical significance at $5 \%$.

\begin{tabular}{llcc}
\hline \multicolumn{1}{c}{ Variables } & $\mathrm{F}_{(2,33)}$ & Adjusted $\mathrm{r}^{2}$ & $\begin{array}{c}\beta \text { coefficient } \\
( \pm \text { standard error })\end{array}$ \\
\hline $\begin{array}{l}\text { Cersosaura schreibersii } \\
\text { Insolation }\end{array}$ & 2.15 & 0.06 & $-0.31( \pm 0.01)$ \\
$\quad \begin{array}{l}\text { Mininum temperature } \\
\text { Mabuya dorsivittata } \\
\text { Insolation }\end{array}$ & 3.06 & 0.06 & $0.32( \pm 0.14)$ \\
$\begin{array}{l}\text { Ophiodes striatus } \\
\text { Mininum temperature }\end{array}$ & $9.91^{*}$ & 0.20 & $0.29( \pm 0.01)$ \\
$\begin{array}{l}\text { Teius oculatus } \\
\text { Mininum temperature } \\
\text { Rainfall }\end{array}$ & $8.40^{*}$ & 0.30 & $0.40^{*}( \pm 0.10)$ \\
$\begin{array}{l}\text { The whole assemblage } \\
\text { Mininum temperature } \\
\text { Rainfall }\end{array}$ & $9.12^{*}$ & 0.32 & $0.58^{*}( \pm 0.11)$ \\
\hline
\end{tabular}

dispersion of individuals during the farming activity (Fig. 2). This anguid lizard inhabits wet grasslands, in the bottom of vegetation or inside clumps of Poaceae and Cyperaceae gramineous (Colli and Oliveira website). Thus, regarding its apparently lower mobility when compared to other species of lizards and the cryptic habit of $O$. striatus, we consider the possibility of this species being more sensible to anthropogenic modifications, which limits the specific microhabitats for foraging and/or reproduction. The impact of the Pampa degradation over the reptilian fauna was recently revealed to a snake assemblage and showed that some species depends on native grassland microhabitats (Winck et al. 2007). For instance, the colubrid snake Philodryas agassizii (= Pseudablabes agassizii) tends to disappear after the replacement of grass fields in farmlands (Winck et al. 2007). The use of fire to renews cattle pasture or facilitates cultivation, constitutes a lowcost and quick alternative used by many farmers, even though being illegal in Rio Grande do Sul State. However, besides the individual injuries caused by flames, the fire also damages and disturbs shelters, causes temperature variation, reduces food availability (arthropods, Silvano et al. 2003) and fragments the habitat. Therefore, we believe that an assessment on the habitat re- quirements of this species is necessary in future studies comprising the lizards of the Pampa biome.

The incidence of lizard captures was typically seasonal and associated to the warmest period for most analyzed cycles. A recent study in the southern Brazil showed that the temporal distribution of anurans was also seasonal and related to the period with the highest temperatures and longest photoperiods (Both et al. 2008). Thus, the unimodal pattern of the temporal distribution of the lizard species was already expected, since the studied area is located in a subtropical region with well-defined climatic seasons, regarding the temperature. In fact, the mean angle recorded in the circular analysis for the two first analyzed cycles coincided with the highest means of temperature $\left(24.9^{\circ} \mathrm{C}\right.$ in January 2002 , and $25.3^{\circ} \mathrm{C}$ in January 2003). The regression analysis corroborated ours statements, since only the temperature explained the seasonal pattern of the lizard capture. Thus, the absence of influence of monthly accumulated precipitation on the lizard incidence was expected due to the uniform distribution of rain in the studied region, as reported to other groups of ectotherms in high latitudes (Winck et al. 2007, Both et al. 2008, Santos et al. 2008, Winck et al. in press).

We recorded an elevated number of females cap- 
tures in months with the highest temperatures possibly dispersing or searching for nest sites (see Overall 1994). Likewise, the higher activity for males was also recorded in higher-temperature months, but beginning before the females activity. This observed pattern is probably due to mate searching, food resource gathering, and dispersal and/or territory seeking (Gibbons and Semlistch 1987). Among the species of temperate regions, the reproductive activity is generally seasonal, with temperature and photoperiod as determinant factors (Mayhew 1961). The variation in the annual thermal amplitude and the hours of sunlight can determine an aestivation period for many species (Mayhew 1961, Licht 1973). This was recently recorded in the Brazilian subtropical region for Teius oculatus (Cappellari 2005) and Tupinambis merianae (Winck and Cechin 2008).

We verified through similarity and regression analyses that the species from this Pampean lizard assemblage differed in patterns of temporal distribution. The annual activity of Teius oculatus was explained by temperature and limited by the rigorous of cold periods (April to October). In contrast, the other species demonstrated a wide temporal distribution without any relation with the tested climatic variables. The relation between temporal occurrence of T. oculatus and temperature is probably due to the heliophilic thermoregulatory behavior of this species and its thermal tolerance. This result (allied to the chi-squared one) corroborates the inactivity period recorded for this species by Cappellari (2005), when the lizards were restricted to burrows due to winter dormancy.

The temporal distribution analysis of Cercosaura ocellata petersi was sub-evaluated due to its rarity in the studied area. However, our records indicates that $C$. schreibersii, Ophiodes striatus, and Mabuya dorsivittata are more tolerant to seasonal climatic variations, since individuals of these species were also captured during the cold season (May to August). This last result can be related to the low thermal fluctuations in the bottom layer of the Pampean grassy fields where these species inhabit, as well the thermoregulatory advantages of a small body (i.e., a higher relation surface-volume). Theoretically, small bodied-size lizards are able to decrease the body temperature faster than larger lizards due to the surface/volume relation, which requires a continu- ous exposition to the sunlight (Pavan 2007). By increasing body size, the surface/volume ratio also increases, the velocity of temperature variation decreases, and the optimal temperatures rise to lethal levels (Pavan 2007). Hence, the slower reduction of body temperature allows the utilization of shadowed habitats. A study showing the exploitation of open formations by smaller species and shadowed areas by larger species was already conducted in the Central America (Hillman 1969). Unfortunately, we did not measure the temperatures of substrates and lizards during the present study due to sampling method, and there are no studies conducted in a similar area to corroborate our considerations to the recorded species. Thus, we suggest that these hypotheses must be tested in future studies concerning patterns of activity of the lizards in the Pampa biome.

Differences in sexual proportion were recorded for two species, Mabuya dorsivittata and Ophiodes striatus. These observations could be a consequence of the comparatively earlier sexual maturation of males plus different sexual behavior, or even to the capture method used (Parker and Plummer 1987). Males tend to move more than females, and one of the consequences is their higher exposure to predators during the reproductive season (Whiting et al. 1996, Greene 1997). Considering that there were no differences in sexual proportion for the other species, it is probable that the results for $M$. dorsivittata and $O$. striatus were due to sampling methodology, since all the capture mechanisms are tendentious, and therefore selective (Greenberg et al. 1994. To a more detailed discussion, see Winck et al. 2007).

The Pampa biome has been suffering an increased degradation not only in the Brazilian lands, but also in Argentina and Uruguay. For instance, the biome holds a rich avifauna of grassland-specialist species, of which approximately 25 are threatened or near-threatened at the global level (BirdLife International 2000). Also, Liolaemus multimaculatus, a typical lizard species from the Atlantic cost of Buenos Aires and Río Negro provinces, which is included in Pampean region, is considered "vulnerable" (Kacoliris et al. 2006). In Uruguay, the grassland-specialist snake species Philodryas agassizii (=Pseudablabes agassizii) is under the status of "maximum priority for conservation" (Morales Fagundes and Carreira Vidal 2000), although we believe that 
this species should be included in the Brazilian threatened animals list, as former discussions (Winck et al. 2007). The negative effects of habitat degradation have been recorded in snakes occurring in the same area of the present study (Winck et al. 2007). In the past three decades, approximately $25 \%$ of the grassland area has been lost due to land use changes, and this trend continues due to the conversion of remaining natural habitats for agriculture, and degradation through over-grazing (Overbeck et al. 2007). Despite this, the conservation units of the Pampa grasslands are extremely rare (less than $0.5 \%$ of the biome is protected). Even so, as Overbeck et al. (2007) state, the management in most of these units is inadequate to preserve the grasslands, as grazing and fire are important factors for their persistence. Accordingly, we urge the authorities from these countries to assess the situation of the recent populations in the biome. Since the free trade agreement among Argentina, Brazil, and Uruguay is settled (Mercosur), we consider that this kind of proximity could provide a framework in the near future to implement policies of conservation programs in the Pampa biome.

\section{ACKNOWLEDGMENTS}

We appreciated the trap reviewing of all the trainees who aided from the Herpetology Lab (UFSM). Also, we are grateful for the collaboration of Dr. Marcos Di-Bernardo (in memoriam). Thanks to Dr. Nilton C. Cáceres for reviewing statistical data, and the two anonymous referees for comments and suggestions. We are grateful to Fundação de Amparo à Pesquisa do Estado do Rio Grande do Sul (FAPERGS) and CNPq for financial support (material financing and a scientific initiation scholarship, respectively). GRW thanks Fundação Carlos Chagas Filho de Amparo à Pesquisa do Estado do Rio de Janeiro (FAPERJ) for doctoral scholarship fund (processes n. E-26/100.769/2008 and E-26/100.477/2011). Conselho Nacional de Desenvolvimento Científico e Tecnológico (CNPq) provides fund in research productivity to SZC (process $n$. 303359/2009-9).

\section{RESUMO}

O crescimento da ocupação humana sobre ambientes naturais é uma das maiores ameaças à biodiversidade. Para amenizar os efeitos negativos antropogênicos, é necessário entender as características das populações naturais, e a história natural das espécies. Um estudo foi conduzido com uma assembeia de lagartos de uma área perturbada do Pampa, de fevereiro de 2002 a janeiro de 2004. A assembleia apresentou padrão sazonal unimodal, com recrutamento ocorrendo durante os meses mais quentes. As capturas foram sazonais durante dois dos três anos monitorados, e concentradas nos meses mais quentes. A temperatura mínima explica o número de capturas para a assembleia como um todo. Entretanto, quando as espécies foram analisadas individualmente, a variável explica apenas a ocorrência sazonal de Teius oculatus. A abundância das espécies foi significativamente distinta no terceiro ano de estudo para Cercosaura schreibersii e Ophiodes striatus. Essa última espécie não teve mais registros na área de maio de 2003 até o final do estudo. Assim, O. striatus pode ser mais sensível às mudanças ambientais, considerando os eventos de mudança na vegetação ocorridas durante o estudo. Com as frequentes e crescentes perturbações ambientais que o bioma vem sofrendo, são necessárias ações de conservação, e dar suporte para o aumento do conhecimento dos lagartos pampeanos.

Palavras-chave: campos sulinos, padrões de atividade, sazonalidade, répteis, padrão unimodal.

\section{REFERENCES}

ANDREWS RM. 1988. Demographic correlates of variable egg survival for a tropical lizard. Oecologia 76: 376-382.

Ávila RW, KaWASHITA-RibEIRO RA, FERREIRA VL AND STRÜSSMANN C. 2010. Natural History of the Coral Snake Micrurus pyrrhocryptus Cope 1862 (Elapidae) from Semideciduous Forests of Western Brazil. S Am J Herpetol 5(2): 97-101.

ÁvILA-PIRES TCS. 1995. Lizards of the Brazilian Amazonia (Reptilia: Squamata). Zool Verhand 299: 1-706.

Balestrin RL, Cappellari LH And Outeiral AB. 2010. Reproductive biology of Cercosaura schreibersii (Squamata, Gymnophthalmidae) and Cnemidophorus lacertoides (Squamata, Teiidae) in Sul-Riograndense Shield, Brazil. Biota Neotrop 10(1): 131-139.

Bergallo HG and Rocha CFD. 1993. Activity Patterns and Body Temperatures of Two Sympatric Lizards with Different Foraging Tactics in Southeastern Brazil. Amphibia-Reptilia 14(7): 312-315.

Bertoluci J. 1998. Annual Patterns of Breeding Activity in Atlantic Rainforest Anurans. J Herpetol 32(4): 607-611. 
BirdLife InTERnAtional. 2000. Threatened Birds of the World. Barcelona and Cambridge, UK: Lynx Editions, $852 \mathrm{p}$.

Both CC, Kaefer IL, SAntos TG And Cechin SZ. 2008. An austral anuran assemblage in the Neotropics: seasonal occurrence correlated with photoperiod. J Nat Hist 42: 205-222.

Budke JC, Ghiel ELH, Athayde EA, Eisinger SM AND ZÁCHIA RA. 2004. Florística e fitossociologia do componente arbóreo de uma floresta ribeirinha, arroio Passo das Tropas, Santa Maria, RS, Brasil. Acta Bot Bras 18(3): 581-589.

Bujes CS AND Verrastro L. 2008. Annual activity of the lizard Liolaemus occipitalis (Squamata, Liolaemidae) in the coastal sand dunes of southern Brazil. Iheringia, Ser Zool 98(1): 156-160.

Canavero A, Arim M, Naya De, Camargo A, Rosa I AND MANEYRO R. 2008. Calling activity patterns in an anuran assemblage: the role of seasonal trends and weather determinants. North-West J Zool 4: 29-41.

CAPPellari LH. 2005. História natural de Teius oculatus (Sauria: Teiidae) no sul do Brasil (Dom Feliciano, Rio Grande do Sul). Unpubl. DSc. thesis, Pontifícia Universidade Católica do Rio Grande do Sul, Brasil.

CEI JM. 1993. Reptiles del noroeste, nordeste y este de la Argentina. Herpetofauna de las selvas subtropicales, Puna y Pampas. Torino: Museo Regionale di Scienze Naturali, 949 p.

CEnSKy EJ. 1995. Reproduction in two Lesser Antillean populations of Ameiva plei (Teiidae). J Herpetol 29: 553560.

COLLI GR. 1991. Reproductive ecology of Ameiva ameiva (Sauria: Teiidae) in the cerrado of central Brazil. Copeia 1991: 1002-1012.

Colli GR AND Oliveira LE. 2008. Guia dos Lagartos do Distrito Federal. Accessible at

http://www.unb.br/ib/zoo/grcolli/guia/guia.htm. Captured in $09 / 23 / 2008$.

Di-Bernardo M, Borges-Martins M ANd Oliveira RB. 2003. Répteis. In: FontanA CS ET AL. (Orgs), Livro Vermelho da Fauna Ameaçada de Extinção no Rio Grande do Sul, Porto Alegre: EDIPUCRS, p. 165-188.

Di-Bernardo M, Borges-Martins M, Oliveira RB And Pontes GMF. 2007. Taxocenoses de serpentes de regiões temperadas do Brasil. In: NASCIMENTO LB AND OliveIRA ME (Eds), Herpetologia no Brasil II, Belo Horizonte: Sociedade Brasileira de Herpetologia, p. $222-263$.
Dunham AE And Miles DB. 1985. Patterns of covariation in life history traits of squamate reptiles: the effects of size and phylogeny reconsidered. Am Nat 126: 231-257.

FiszON JT ET AL. 2003. Causas Antrópicas. In: RAMBALDI DM AND OliveIRA DAS (Orgs), Fragmentação de ecossistemas: causas, efeitos sobre a biodiversidade e recomendações de políticas públicas, Brasília: MMA/ SBF, p. 66-99.

García A, Valtierra-Azotla M And Lister BC. 2010. Behavioral responses to seasonality by two Sceloporine lizard species from a tropical dry forest. Anim Biol 60(1): 97-113.

Gibbons JW And Semlitsch RD. 1987. Activity patterns. In: SeIGEL RA ET AL. (Eds), Snakes: Ecology and Evolutionary Biology, New York: McGraw-Hill Publishing Co., p. 184-209.

Greenberg CH, NeAry DG AND Harris LD. 1994. A Comparison of herpetofaunal sampling effectiveness of pifall, single-ended, and double ended funnel traps used with drift fences. J Herpetol 28(3): 319-324.

GREENE HW. 1997. Snakes, the evolution of mistery in nature. Berkeley: University of California Press, 366 p.

hatano FH, Vrcibradic D, Galdino CAB, CunhaBArros MC, Rocha CFD AND VAN SLUYs M. 2001. Thermal ecology and activity patterns of the lizard community of the restinga of Jurubatiba, Macaé, RJ. Rev Bras Biol 61(2): 287-294.

Hillman PE. 1969. Habitat specificity in three sympatric species of Ameiva (Reptilia: Teiidae). Ecology 50(3): 476-481.

IBGE. 2008. Elaboração Agrícola Municipal - 04/2008. SEPLAG/DEPLAN. Accessible at http://www.scp.rs.gov.br. Captured in 10/06/2008.

Kacoliris F, Horlent N And Williams J. 2006. Herpetofauna, Coastal Dunes, Buenos Aires Province, Argentina. Check List 2(3): 15-21.

Kovach WL. 1994-2006. Oriana - Circular Statistics for Windows. User's Manual. Ver. 3 Kovach Computing Services, Pentraeth, Wales, UK, 155 p.

Krebs CJ. 1999. Ecological Methodology. $2^{\text {nd }}$ ed., Menlo Park: Addison-Welsey Ed. Publ., 624 p.

LiCHT P. 1973. Environmental influences on the testis cycles of the lizards Dipsosaurus dorsales and Xantusia vigilis. Comp Biochem Physiol 45: 7-20.

MagurRan AE. 2004. Measuring Biological Diversity. Dordrecht: Blackwell Kluwer Academic Publ, 256 p. 
MALUF JR. 2000. Nova classificação climática do Estado do Rio Grande do Sul. Rev Bras Agrometeorol 8(1): 141-150.

Marques OAV, Eterovick P ANd ENDo W. 2001. Seasonal activity of snakes in the Atlantic Forest in southeastern Brazil. Amphibia-Reptilia 22: 103-111.

MAYHEW WW. 1961. Photoperiodic response of female fringe-toed lizards. Science 134: 2104-2105.

MMA - Ministério do Meio Ambiente, dos RecurSos Hídricos E dA AMAZÔNIA LEgAL. 2000. Avaliação e ações prioritárias para a conservação da biodiversidade da Mata Atlântica e Campos Sulinos. Brasília: Conservation International do Brasil/Fundação SOS Mata Atlântica/Fundação Biodiversitas, 40 p.

Montechiaro L, KaEFer IL, Quadros FC ANd CECHIN SZ. 2011. Feeding habits and reproductive biology of the glass lizard Ophiodes cf. striatus from subtropical Brazil. N West J Zool 7(1): 57-67.

Morales Fagundes S AND Carreira Vidal S. 2000. Calificación del estado de conservación de la fauna de ofidios (Reptilia, Serpentes) de Uruguay. FACENA 16: $45-51$.

NIEWIAROWSKI PH. 1994. Understanding Geographic LifeHistory. In: VitT LJ AND PIANKA ER (Eds), Lizard Ecology, New Jersey: Princeton University Press, p. 3149.

Overall KL. 1994. Lizard Egg Environments. In: Vitt LJ AND PIAnKa ER (Eds), Lizard Ecology, New Jersey: Princeton University Press, p. 51-72.

Overbeck Ge, Muller SC, Fidelis A, Pfandenhauer J, Pillar VD, Blanco CC, Boldrini II, Both R AND FORNECK ED. 2007. Brazil's neglected biome: The South Brazilian Campos. Perspect Plant Ecol 9(2): 101-116.

Parker WS ANd Plummer MV. 1987. Population ecology. In: SeIGEL RA ET AL. (Eds), Snakes: Ecology and Evolutionary Biology, New York: McGraw-Hill Publishing Co., p. 253-301.

PaVAn D. 2007. Assembléias de répteis e anfíbios do Cerrado ao longo da bacia do rio Tocantins e o impacto do aproveitamento hidrelétrico da região na sua conservação. Instituto de Biociências (IB), Depto de Zoologia, São Paulo. Accessible at http://www.teses.usp.br/teses/ disponiveis/41/41133/tde-05032008-095752/.

Peloso PL, Rocha CFD, Pavan SE and Lucena S. 2008. Activity and microhabitat use by the endemic whiptail lizard Cnemidophorus nativo (Teiidae) in a restinga habitat in the State of Espírito Santo, Brazil. S Am J Herpetol 3: 89-95.

Pereira PRB, Netto LRG, Borin CJA ANd SARTori MGB. 1989. Contribuição à geografia física do município de Santa Maria: unidades de paisagem. Geogr Ens Pesq 3: 37-68.

Prado CPA, Uetanabaro M and Haddad CFB. 2005. Breeding activity patterns, reproductive modes, and habitat use by anurans (Amphibia) in a seasonal environment in the Pantanal, Brazil. Amphibia-Reptilia 26(2): 211-221.

Rodrigues MT. 2005. The Conservation of Brazilian Reptiles: Challenges for a Megadiverse Country. Conserv Biol 19(3): 659-664.

ROHLF FJ. 2000. NTSYS-pc: numerical taxonomy and multivariate analysis system. Version 2.1. New York: Exeter Software.

Romesburg H. 1984. Cluster Analysis for Researchers. Malabar: Robert E. Krieger Publishing Company, 16 p.

Santos TG, Kopp K, SpIEs MR, TREVISAN R AND CECHIN SZ. 2008. Distribuição temporal e espacial de anuros em área de Pampa, Santa Maria, RS. Iheringia Ser Zool 98: 244-253.

Santos TG, Rossa-Feres D and Casatti L. 2007. Diversidade e distribuição espaço-temporal de anuros em região com pronunciada estação seca no sudeste do Brasil. Iheringia Ser Zool 97(1): 37-49.

Silvano DL, Colli GR, Dixo MBO, Pimenta BVS AND WIEDERHECKER HC. 2003. Anfíbios e répteis. In: RAMBALdi DM AND Oliveira DAS (Eds), Fragmentação de ecossistemas: causas, efeitos sobre a biodiversidade e recomendações de políticas públicas, Brasília: MMA/SBF, p. 184-200.

STATSOFT INC. 2001. STATISTICA (data analysis software system). Version 6. Available from: www.statsoft.com.

SYSTAT. 2004. Systat for Windows. Version 11. Systat Software Inc.

TINKLE DW. 1967. The life and demography of the sideblotched lizard, Uta stansburiana. Misc Publ Mus Zool 132: $1-182$.

Toledo LF, Zina J AND HadDAD CF. 2003. Distribuição Espacial e Temporal de uma Comunidade de Anfíbios Anuros do Município de Rio Claro, São Paulo, Brasil. Holos Environm 3(2): 136-149.

VAN Sluys M AND Rocha CFD. 1999. Tupinambis merianae (Common tegu). Activity. Herpetol Rev 30(1): $42-43$.

VAn Sluys M, Rocha CFD, VRcibradic D, Galdino CA AND FONTES AF. 2004. Diet, activity and micro- 
habitat use by two sympatric Tropidurus species (Lacertilia: Tropiduridae) in Minas Gerais, Brazil. J Herpetol 38(4): 606-611.

VitT LJ. 1987. Communities. In: Seigel RA ET AL. (Eds), Snakes: Ecology and Evolutionary Biology, New York: McGraw-Hill Publishing Co., p. 335-365.

VRCIBradic D, CUnHA-BARRos M AND Rocha CFD. 2004. Ecological observations on Mabuya dorsivittata (Squamata: Scincidae) from a high altitude habitat in south-eastern Brazil. Herpetol J 14: 109-112.

VRCIBRADIC D AND ROCHA CFD. 1996. Ecological differences in tropical sympatric skinks (Mabuya agilis and Mabuya macrorhyncha) in Southeastern Brazil. J Herpetol 30(1): 60-67.

VRCIBRADIC D AND Rocha CFD. 1998. Reproductive cycle and life-history traits of the viviparous skink Mabuya frenata in southeastern Brazil. Copeia 1998: 612-619.

WALDSCHMIDT S AND TRACY CR. 1983. Interactions between a Lizard and Its Thermal Environment: Implications for Sprint Performance and Space Utilization in the Lizard Uta stansburiana. Ecology 64(3): 476-484.

Whiting MJ, Dixon JR And GReEne BD. 1996. Measuring snake activity patterns: the influence of habitat heterogeneity on catchability. Amphibia-Reptilia 17: 47-54.

Wiederhecker HC, Pinto ACS ANd Colli GR. 2002. Reproductive Ecology of Tropidurus torquatus (Squamata: Tropiduridae) in the Highly Seasonal Cerrado Biome of Central Brazil. J Herpetol 36(1): 82-91.
Wiederhecker HC, Pinto ACS, PAIVA MS ANd COLli GR. 2003. The demography of the lizard Tropidurus torquatus (Squamata, Tropiduridae) in a highly seasonal Neotropical savanna. Phyllomedusa 2(1): 9-19.

Winck GR, Blanco CC AND CECHIN SZ (in press). Population Ecology of Tupinambis merianae (Squamata, Teiidae): Home-range, Activity and Space Use. Anim Biol.

WINCK GR AND CECHIN SZ. 2008. Hibernation and emergence pattern of Tupinambis merianae (Squamata: Teiidae) in the Taim Ecological Station, southern Brazil. J Nat Hist 42(3): 239-247.

Winck GR, SAntos TG And CeChin SZ. 2007. Snake assemblage in a disturbed grassland environment in Rio Grande do Sul State, southern Brazil: the case of populational fluctuations of Liophis poecilogyrus and Pseudablabes agassizii. Ann Zool Fenn 44: 321-332.

ZALUAR H AND RochA CFD. 2000. Ecology of the wideforaging lizard Ameiva ameiva (Teiidae) in a sand dune habitat of southeast Brazil: ontogenetic, sexual and seasonal trends in food habits, activity, thermal biology and microhabitat use. Cien Cult 52(2): 101-107.

ZAR JH. 1999. Biostatistical Analysis, $4^{\text {th }}$ ed., New Jersey: Prentice Hall, 929 p. 